\title{
THE REPRESENTATION OF TECHNOLOGICALLY LITERATE ULEMA IN THE TELEVISION DRAMA "TUKANG BUBUR NAIK HAJI"
}

\author{
Dr. Cecep Alba ${ }^{1}$ \\ Faculty of Art and Design, Institut Teknologi Bandung (ITB), Indonesia. \\ (Email: cecep_alba@yahoo.co.id) \\ Ade Engkus Kusnadi, S.Pd., M.Pd.² \\ Faculty of Art and Design, Institut Teknologi Bandung (ITB), Indonesia. \\ (Email: ade.engkuskusnadi@itb.ac.id) \\ Syarif Maulana, S.IP., M.I.Kom ${ }^{3}$ \\ Faculty of Art and Design, Universiti Teknologi Mara (ITB), Indonesia. \\ (Email: syarafmaulini@gmail.com)
}

Received date: $17-06-2019$

Revised date: $26-07-2019$

Accepted date: $21-08-2019$

Published date: 10-09-2019

To cite this document: Alba, C., Kusnadi, A. E., \& Maulana, S. (2019). The Representation of Technologically Literate Ulema in The Television Drama "Tukang Bubur Naik Haji". International Journal of Heritage, Art and Multimedia, 2(6), 41-50.

DOI: $10.35631 /$ ijham.26005

Abstract: Tukang Bubur Naik Haji (TBNH) was one of the most popular television dramas in Indonesia. The popularity was measured either by its long-running drama episodes - i.e. from the year 2012 until 2017. In the outline, the story was about the Jakartans daily life with the figure of Bang Sulam as the main character. Bang Sulam was a chicken porridge seller who aspired to perform Hajj (Islamic pilgrimage to Mecca) as a part of Five Pillars of Islam. In $T B N H$, there were a number of scenes that represented the existence of ulema (Islamic cleric) in the midst of society. The ulema was not only propagated religious messages conventionally but also used technology as a more effective means of delivery. The delivery of religious messages through this technology channel was analysed by semiotic and multimodality approaches. Through these methods, a number of scenes in TBNH were examined and viewed from various sides such as the camera angle, text analysis, the actor's gaze direction, the color semiotics of the attribute, etc. The result of this study showed a technologically literate ulema represented by breaking the fourth wall, the use of tools in delivering messages, white as a symbol of purity, and the adapted text to the montage scenes.

Keywords: Ulema, Technology, Multimodality, Tukang Bubur Naik Haji

\section{Introduction}

Since the 1920s, television has been developed by John Logie and become one of promising mass product on the economy, the effectivity of information publication, to cultural aspects. Television has an image of an interesting product because it serves a moving picture, texts, and 
sound that merge into one display compared to old separate media such as text presented in newspaper and sound in radio.

These television wonders are measured from its deployment to the whole world, to its functional status from tertiary to secondary until, now, as a primary need. This primary need status is linked to the variety of its quality. At first, television was produced only in one type and one price. However, along with technology development, television starting to have more variety or quality. There is high-quality television at a higher price until a lower one with a relatively cheaper price. In a certain society's perception, the higher or lower price is not the main problem in terms of the television's content itself. Because both categories can still have the same broadcasting programs without any alteration.

That kind of thoughts is quite helping in television's massification to society even to the midlower economy one. The target market has been expanded and it is no more has a status of being an elite property. Almost every circle have it without depending on their economic status because of the affordable cost. This fact of mass possession of a television naturally become a consideration for a television station about what kind of program that should be broadcasted. Whether the aired program is a vast public consumption and the cultural aspects caused by it more or less will be present.

One of the general public consumption from television is soap opera. In Indonesia, the soap opera term —or sinetron in Indonesian, an acronym of electronic cinema-firstly triggered by Soemardjono, one of the founders of the Jakarta Institute of Art (Institut Kesenian Jakarta, IKJ). It was called an electronic cinema because it is a serial cinema (film) broadcast that is watched from an electronic media (in this case, television). Soap opera differ from the film. Soap opera is a serial broadcast that was made with dozens of episodes, meanwhile, a film is an individual broadcast with shorter duration.

Traced from its history, the soap opera trend in Indonesia arise in the 90s. In that era, private television stations started to emerge in Indonesia after the prior one and only television broadcaster, TVRI, owned by the government. Losmen was believed to be the pioneer of soap opera on screen - although there was an opinion that Marlia Hardi was the first soap opera. Nevertheless, the term soap opera was firstly used on serial drama Jendela Rumah Kita (1989). Throughout the 90s, the soap opera term started to be used vastly. The airing of soap opera then started to dominate private television channels such as Lenong Rumpi, Si Cemplon, Si Doel Anak Sekolahan, et cetera. Between the soap operas in that era, Si Doel Anak Sekolahanfeaturing Rano Karno as the main actor -is the most popular program and has a place in people's heart. One of the barometers is the fact that Si Doel Anak Sekolahan has been made in several sequels.

Entering the year 1995 until 1998, there was a slight shift in the theme of soap opera. The directors started to make a soap opera that was adapted from a big-screen movie in the $80 \mathrm{~s}$, for example, Lupus, Olga, and Catatan Si Boy. After that, in 1998, Multivision Plus as one of the production house in Indonesia made a soap opera titled Tersanjung. This is the longest soap opera ever made in that era, consist of 356 episodes divided into several sequels.

In this contemporary era, a soap opera has become more diverse. In Indonesia, a soap opera with religion theme has gained quite much interest. A religion-themed soap opera is a soap opera that use deity or religious themes as the highlight in the scenario. Several famous soap 
operas with religion theme are Para Pencari Tuhan, Lorong Waktu, and Tukang Bubur Naik Haji.

Based on pre-study towards those religion theme soap operas, at least there is a character that has always exist and involved in almost every episodes. That character is an ulama (an Islam theologian) that often use strong religious symbols - in this context, Islamic symbols. For example, in the soap opera titled Para Pencari Tuhan, there is a character named H. Ahmad Zackaria or Bang Jack played by Dedi Mizwar. Bang Jack is a mushola (an Islam prayer room) keeper who then helping three recidivists named Chelsea, Barong, and Juki to give them religion knowledge.

Meanwhile, in the soap opera titled Lorong Waktu, there is a character named Haji Husin played by Deddy Mizwar and Ustad Addin played alternately by various actors (depend on the season) namely Adjie Pangestu, Dicky Chandra, and Hefri Olifian. Ustad Addin is the inventor of the time machine that travelled him to the past or future so he could teach some life values. He travelled with Haji Husin, his foster father, and a junior student named Zidan.

In the soap opera titled Tukang Bubur Naik Haji, there is a character named Ustad Zakaria played by El Manik and Ustad Yusuf played by Yusuf Mansur. Although both of them is not a central character in the soap opera, either Ustad Zakaria or Ustad Yusuf have been present several times in Tukang Bubur Naik Haji to amplify the religion theme carried.

From several phenomena that have been shown in the pre-study, it can be concluded temporarily that the ulama figure is the most central figure in soap opera that carried religion themes. That figure raised with various stereotype attributes, attitude, and typical expressions so the viewers have no difficulty to recognize the ulama character.

However, on the other side, it is also important to analyze a soap opera with a more critical point of view. A soap opera can be representing someone based on an image that has already formed in society. Vice versa, a soap opera can be making a new representation so that the said image would be accepted later in society. So simply said, it can be interpreted that a soap opera can be a party that contribute to making new stereotypes in society such as, for example, a male protagonist generally has a fair skin, short-haired, and slender; a female protagonist generally has a fair skin, long-haired, and slender; so is ulama figure that wear peci (Islamic headwear), Koko shirt, sarong or trousers, and grow a beard.

On that basis, the researcher team formalizes a study with a focus on "The Representation of Technology Literate Ulama in Soap Opera (Roland Barthes Semiotic Analysis in the Soap Opera: Tukang Bubur Naik Haji)". This study is restricted on the soap opera titled Tukang Bubur Naik Haji with considerations as follows:

1. Tukang Bubur Naik Haji has finished its airtime in 2017 so the ulama character that has been exposed would have no more development on the following episodes. Actually, Lorong Waktu has also finished its airtime in 2006, but Tukang Bubur Naik Haji is chosen considering it as the latest issue.

2. The ulama image in Tukang Bubur Naik Haji is not constantly appeared except for particular episodes. This is more likely for the researcher team to do a narrowed but profound study.

3. The ulama image that appeared in Tukang Bubur Naik Haji has a diverse background in real life. El Manik as Ustad Zakaria in truth is not an ulama, meanwhile, Yusuf 
Mansyur as Ustad Yusuf is originally an ulama in daily life. This diverse phenomenon may also be enabling a more diverse conclusion from the researcher.

Using Roland Barthes semiotic analysis, a more visible denotation, connotation, and myth that usually included in ulama image representation are expected. This study is expected to be a reference to other researchers especially regarding how a soap opera has the ability to produce a certain image that potentially can become a stereotype in society.

\section{Problem Statement}

The question in this study is as follows: How do ulemas display technological literacy in the soap opera Tukang Bubur Naik Haji?

\section{Objective}

The objectives of this study are as follows:

1. Providing knowledge to soap opera viewers about how ulemas are represented as competent in technology literacy through some techniques in the world of television.

2. Providing knowledge for soap opera viewers to understand about how the image of the ulemas is formed through images on television.

\section{Research Scope}

The scope of this research is the soap opera Tukang Bubur Naik Haji episode "Yusuf Mansur" and other episodes that represent ulemas.

\section{Literature Review}

There are two points will be discussed in this literature review, namely multimodality and semiotics.

\section{Multimodality}

Simply made, multimodality is a presumption that all of the meaning (written or drawn) are complexly produced, built from historical, cultural, and medium of communication aspects, until detailed stuff such as typography, colors, to the sizing of the picture and writing.

This knowledge is believed rooted in the rhetorical theory in the Ancient Greece era around the $4^{\text {th }}$ B.C. In that era, rhetoric is a theory about how to convey an argument in public. But more than that, rhetoric also needs to consider several aspects. For example, Aristoteles has mentioned three important elements: ethos, pathos, and logos. Ethos stands for the speaker's credibility, pathos for the speaker's ability to sympathize the audiences, and logos for plausibility (it means that what is being conveyed must contain the truth value).

Rhetoric theory becomes a ground assumption that every communication conveyed, basically comprised complexity and even multidimensional. However, at that time, there is no such term as "multimodality". The term only emerged in $20^{\text {th }}$-century when Gunther Kress and Theo van Leeuwen published a book titled Reading Images: The Grammar of Visual Design. In that book, the term multimodality was mentioned as a way to "read" an advertisement from a linguistic perspective.

Nevertheless, prior to Kress and van Leeuwen, in the 1960s and 1970s, tendencies toward multimodality have begun to appear from technological development especially in recording media. In that period, a literature lecturer, Donald Murray, often courage his apprentices to write based on their observation. The students have to comport oneself as a rolling camera. 
That method looked like a mere one at first. But at that time, there was a spirit called "expressionism" from euphoria towards a new technological development such as film, photography, and audio devices. Those tools, howsoever, made us feel that we can have an extended scope than we supposed to. Several authors then also utilize those technologies to expand their imagination for writing and make it a new medium to meld their ideas.

On the next decade, the two researchers named James Berlin and Joseph Harris discovered a strong connection between the world of narrations with the world of creativity around it such as fine art and music. Berlin and Harris revealed that a writing capability is an ability of "cognition multimodality". A writing capability is actually built by sensitivity towards various things such as visual, musical to kinesthetics elements. It can be concluded that a text produced by an author is actually has a complex background.

Finally, in 1996, the idea of multimodality has been confirmed through the book titled Reading Images: The Grammar of Visual Design authored by Gunther Rolf Kress, professor of London University, and Theo van Leeuwen, lecturer of University of Technology, Sydney. Inside the 288 pages book, has been revealed the in-depth ways to dissect the image structures through the multimodality approach. Kress and van Leeuwen said that multimodality was also assumed that the source of meaning was not limited to the language, but can also be referred to images, sounds or spaces that have been used as a medium to convey information and offer purposive ideas. They even argued that color is one of the elements that produced a meaning. Furthermore, the layout can also determine a meaning.

Multimodality has several assumptions. The first assumption is a multiple representation and communication form are always containing elements multiplicity and each of them contributes to constructing meaning. The elements multiplicity consist of the visual, spoken words, gesture, written text, three-dimensional aspect, et cetera.

Secondly, multimodality assumed that the meaning of representation or communication is gradually formed by an individual or society. The more often a representation or communication used in a community, the meaning behind it will become more visible and wellarticulated.

Thirdly, to build a representation and communication, a communicator will certainly considerate the elements as a building block of a certain message can interact with communicant. In short, the communicator must have purpose and interests. In multimodality assumptions, there is no communicator that aimlessly create a representation or communication. There always be a certain purpose and this is what will later be read.

This multimodality is also consist of three aspects, the representation component, interpersonal or interactional component, and textual component. The representation component means an object has an ability to represent aspects of the world's experience outside the symbolic systems either directly or indirectly. For example, the picture of an apple represents the "real apple”.

An interpersonal or interactional component means every object must be able to connect the purpose of a maker with the meaning accepted by the receiver. For example, in a beauty advertisement, the advertisement maker wants the consumer to remember the product instead of the female model. But instead, the consumer remembers the female model more than the 
product. This interpretation dialogue becomes one of the most important aspects of multimodality.

Lastly, a textual component means that every object has to be arranged like a language that has a readable structure. That means, even though the displayed picture is an advertisement, it also contains a narration just like a sentence. For example the picture is to be seen from left to the right, just like the usual reading pattern of an Indonesian people, or a picture can also have a connotative and denotative meaning just like a language.

\section{Semiotics}

The semiotics or semiology is a term referred to the knowledge that studies a symbolic system such as codes, signals, et cetera. To put it simply, semiotics is a study of the sign, taken from a Greek word semioin means sign. As mentioned before, human, in their life, has abilities to produce and process various symbols. Larry Samovar in his book titled Komunikasi Antar Budaya (2010) mentioned that these abilities include receiving, saving, processing, and publish symbols that differ human from the other living beings. Semiotics examines symbols of signs, study the function of signs in a text where a symbolic system contained in a text has a certain message that direct the reader into accepting that message to be meant. Daniel Chandler in his book titled Semiotics for Beginners (2006) as a collection of signs (such as words, pictures, sounds and/or gestures) that is constructed (and interpreted) referring to the convention associated with a certain genre and communication media.

This concept began with the thought of Ferdinand Saussure as a linguistic expert that saw semiotics as a study to examine signs, the process of sign, and signing, through a sign system that has been divided in two groups: the signifier and the signified, a model developed by Saussure by seeing the signifier as a certain perception form from a sign or the image of a sign. Meanwhile, the signified is a form of a mental concept associated with the sign itself. The dyadic relations between the signifier and the signified is arbitrary, in another word, a random relationship not a standardized pattern relationship. However, Saussure emphasized that the relation constructed between the signifier and the signified is not a personal matter but instead a social agreement.

A relation between the signifier and the signified is a combination of the sign component where the relationship between them is the meaning itself based on Saussure's theory. As an example, the word "Hot" as the signifier when it pinned on the stove as the signified then it will have a meaning of the heat from the burning stove and would be dangerous to be touch. But yet, when it pinned on the other signified such as a chicken wing - becomes a hot chicken wing - the meaning would be altered into the spiciness level of food.

The thoughts of Saussure later became a foundation for Roland Barthes to develop further semiotics or semiology application as a study. Differ from Saussure that focused on the relationship between the signifier and the signified, and the meaning revealed in that dyadic relation, Barthes in his books titled Elemen-Elemen Semiologi (2012) and Membedah MitosMitos Budaya Massa (2007) have a further point of view regarding signifier concept in a deeper order (connotative), where the prior theory of Saussure focused on the denotative order. Roland Barthes saw a language as a sign system that reflecting a certain society's assumptions at a certain time (Sobur, 2003: 63).

As well as Saussure's theory, Barthes also believe that between the signifier and the signified is not naturally formed, but instead an arbitrary in nature. While Saussure only emphasizes in 
signifier on the denotative order, Barthes completed Saussure's semiology with a developed signifier system on the connotative order. Barthes also saw another aspect from the signifier: a myth that defines a society.

\begin{tabular}{|l|l|}
\hline $\begin{array}{l}\text { Signifier } \\
\text { Signified }\end{array}$ & \\
\cline { 1 - 1 } $\begin{array}{l}2 . \\
\text { Denotative Sign }\end{array}$ & \\
\hline $\begin{array}{l}2 . \\
\text { Connotative Signifier }\end{array}$ & $\begin{array}{l}\text { 3. } \\
\text { Connotative } \\
\text { Signified }\end{array}$ \\
\hline $\begin{array}{l}4 . \\
\text { Connotative Sign }\end{array}$ & \\
\cline { 1 - 2 } &
\end{tabular}

\section{Table 1. Barthes' Map of Sign (Sobur, 2003: 69)}

On the map of sign developed by Barthes, it can be seen how the denotative sign (3) has been made from a relation between the signifier (1) and the signified (2). However, at the same time, the denotative sign also could become a connotative sign (4). Denotation in Barthes point of view is the first order with a closed meaning. Denotation presents a simple, direct, and definite meaning. Denotation is the real meaning or literal thing that has been agreed upon society, referring to reality.

A connotative sign is a sign that is built from the relation where the signifier has an implicit (vague), indirect, and indefinite meaning, in other words, there is a vast possibility for new interpretations. In Barthes semiology, the relation in denotative sign is described as the first order of significance system, while the connotative sign is the second order of significance system. It can be said that denotation is a permanent objective meaning, while connotation is a diverse and subjective meaning.

Barthes appended some thought about the meaning of a sign, through the second step of significance that revealed the meaning of connotation namely a subjective meaning or at least intersubjective, that related with the content, that a sign worked through a myth as the most profound layer of the signified and meaning. Back to the "hot" sign as mentioned above, the signifier pinned on a stove as the signified will bring up the denotative sign meaning as the stove's heat, but the new meaning - connotatively_can emerge when the signifier "hot" pinned on a woman or sensuality as the signified and could be interpreted connotatively as a sexy woman that "burns" your lust.

There is a difference between interpreting a denotation and connotation a la Barthes with the meaning of denotation and connotation in general. In general, denotation is interpreted as a literal meaning of an object, a traditional significance process, usually refer to the use of language that has a meaning as spoken literally. However, in Barthes semiology denotation is a first order significance system, while connotation is second order. In this case, denotation is confidentiality of meaning or covered up (repressed) in political meaning, typically a Barthes critique. As the most extreme reaction against the oppressive denotation literality, Barthes tried to eliminate and reject the idea, for Barthes, there is solely a connotation. Moreover, in the Barthes framework, the connotation is identic with an ideology operation, he mentioned it as a 
myth functioning to express and justify the dominant values prevailed in a certain period. Barthes argued that myth is also a second order of the meaning system.

A myth in Barthes point of view has a different concept with the general meaning. Barthes mentioned that myth is a language, so that myth is a communication system and a message. On his argumentation, he proposed that myth in this particular meaning is an expansion of connotation. The actual myth is a connotation that has been formed for a long time in a society. Barthes mentioned that myth is a semiological system, a system of signs interpreted by humans. A myth can be said as a social class product that has a certain dominance. Barthes' myth automatically became a difference with the myth of our understanding as a superstition, illogical, ahistorical, and so on, but the myth by Barthes is a type of speech of someone. In a myth, the signified is allowed to have many signifiers, for example, "sensuality" could have many signifiers from adding the word "hot", a Marilyn Monroe poster, to a stallion.

\section{Methods}

The methods that have been used in this study are focus group discussion, observation, and literature study that each will be described as follows:

\section{Focus Group Discussion}

FGD was held on Thursday, 12 ${ }^{\text {th }}$ July 2018 at GH Universal Hotel, Dr. Setiabudi street, 376, Ledeng, Bandung city, at 10.00 - 14.00 o'clock. There was 14 (fourteen) attendant with the details are as follows: 1 (one) moderator, 1 (one) moderator assistant, 1 (one) minutes of meeting, 1 (one) documentarian, 1 (one) logistic provider, and 8 (eight) participants.

The agenda started by a foreword from the chief researcher followed by background explanation, the first session discussion, break, and the second session discussion.

The FGD's attendant criteria described as follows:

3. Have watched at least five episodes of the Tukang Bubur Naik Haji soap opera

4. A bachelor as a minimum education degree

5. Have a generally open-minded and argumentative

The study object is an episode of Tukang Bubur Naik Haji involving Ustad Yusuf Mansur as the actor. The episode was played twice, at the beginning and the end of the discussion session.

\section{Observation}

The observation was done through the 10 (ten) episodes of Tukang Bubur Naik Haji involving the ulama character. The observation was done by watching the 10 episodes repeatedly, twice at least, and took notes several scenes that believed to have a significant statement.

\section{Literature Study}

A literature study was done to see a linkage between theory and the observed object so that an in-depth meaning in the Tukang Bubur Naik Haji soap opera could be discovered in association with multimodality and semiotics approaches.

\section{Results}

The results of this study discovered so far are as follows:

1. In the soap opera titled Tukang Bubur Naik Haji, the ulama wished that the conveyed message will be universally accepted for all of the audience. It can be seen from how the ulama image repeatedly looked at the camera which means, firstly, carry out the 
"breaking the $4^{\text {th }}$ wall" technique meaning, in performance art theory, to communicate directly to the audience. Secondly, in Krees and van Leeuwen multimodality theory, looking at the camera is also means as an effort to be closer with the audience.

2. In Tukang Bubur Naik Haji, ulama represented as a respected, heard, and influential figure. It was seen from the scenes that dominated by Kuleshov effect editing technique showing as if the audience paying attention to the ulama in front of then with adoring, touched, and realization looks on their faces contemplatively.

3. The ulama represented by a figure that understood technology in practical meaning, shown by the use of a microphone and symbolically shown by the attributes worn that dominated by the white color. According to the color expert, Jennifer Brown, a white color is associated with purity, virginity, innocence, illumination, heavenly, security, brilliance, enlightenment, pure faith, Genesis, sterility, spirituality, probability, mercy, honesty, aegis, tenderness, and perfection.

4. The ulama represented as a religious and spiritual figure, shown by the dominance of praying scenes.

\section{References}

Auter, P. J., \& Davis, D. M. (1991). When Characters Speak Directly to Viewers: Breaking the Fourth Wall in Television. Journalism Quarterly, 68(1-2), 165-171.

Bell, P., \& Milic, M. (2002). Goffman's Gender Advertisements Revisited: Combining Content Analysis with Semiotic Analysis. Visual Communication, 1(2), 203-222.

Blievernicht, D. L. (1967). A Multidimensional Timing Device for Cinematography. Research Quarterly. American Association for Health, Physical Education and Recreation, 38(1), 146-148.

Bligh, A. (1985). The Saudi Religious Elite (ULAMA) as Participant in The Political System of The Kingdom. International Journal of Middle East Studies, 17(01), 37-50.

Custers, K., \& Van den Bulck, J. (2016). The Association Between Soap Opera and Music Video Viewing and Fear of Crime in Adolescents. Communication Research, 44(1), 96116.

De Burgh-Woodman, H., \& Brace-Govan, J. (2008). Jargon as Imagining: Barthes' Semiotics and Excavating Subcultural Communication. Qualitative Market Research: An International Journal, 11(1), 89-106.

Dicks, B., Soyinka, B., \& Coffey, A. (2006). Multimodal Ethnography. Qualitative Research, 6(1), 77-96.

Droit-Volet, S., \& Meck, W. H. (2007). How Emotions Colour Our Perception of Time. Trends in Cognitive Sciences, 11(12), 504-513.

Gerbner, G., \& Gross, L. (1976). Living with Television: The Violence Profile. Journal of Communication, 26(2), 172-199.

Han, C. (2015). How to Do Critical Discourse Analysis: A Multimodal Introduction. Australian Journal of Linguistics, 35(4), 415-418.

Iedema, R. (2003). Multimodality, Resemiotization: Extending the Analysis of Discourse as Multi-Semiotic Practice. Visual Communication, 2(1), 29-57.

Katzman, N. (1972). Television Soap Operas: What's Been Going on Anyway? Public Opinion Quarterly, 36(2), 200.

Kessous, A., \& Roux, E. (2008). A Semiotic Analysis of Nostalgia as A Connection to The Past. Qualitative Market Research: An International Journal, 11(2), 192-212.

Nilan, P. (2001). Gendered Dreams: Women Watching Sinetron (Soap Operas) on Indonesian TV. Indonesia and the Malay World, 29(84), 85-98.

Singhal, A., \& Rogers, E. M. (1988). Television Soap Operas for Development in India. International Communication Gazette, 41(2), 109-126. 
Van Leeuwen, T. (1998). It Was Just Like Magic_-A Multimodal Analysis of Children's Writing. Linguistics and Education, 10(3), 273-305. 